\title{
Performance Management - an Operative Instrument for Effective Decision Making
}

\author{
M. Kavitha, T. Punitha
}

\begin{abstract}
In the global scenario, the focus of the organizations is revolving around performance management world-wide. Employees' performance management is the best way for any organization to ensure continued best performance of its employees thereby achieving their goals effectively. It is to be considered as an important role of HR manager that motivating employees to improve positive impact on organizational as well as individual performance. It can be integrated with talent management for compensation, succession planning and learning solution. Hence emphasis should be made to the key attributes of performance management such as Succession planning, Reward Management, Career management, Training \& Development, Discipline \& grievances and Counselling. After identifying the attributes, the measurement about performances will be made to help the management in administrative, informational and developmental decision making. This paper focuses on effective decision-making process through performance management as succession planning and reward management in administrative decisions, career management and training \&development in informational decisions, Discipline \& Grievances and Counselling in developmental decisions. These inputs will provide evidence-based decision making to improve the business as a whole.
\end{abstract}

Keywords : Performance Management, Succession Planning, Reward Management, Career Management, Training and Development, Counselling.

\section{INTRODUCTION}

$T_{\text {he main action of performance management system in }}$ the software industry is to solve the problems by making an effective decision. Decision making process covers the selection of Administrative decision making, informational decision making, and developmental decision making process. This course of action is taken to bring good results to the problems.

The decision making process comfort the management in higher level of making decision with the hand of some attributes, such as succession planning, Reward management, Training and development, Career management, discipline and grievance and counseling. This aspect of decision making is the back bone of each and every industry, other than this high weighted decision cannot be

Revised Manuscript Received on December 05, 2019.

* Correspondence Author

Dr. M. Kavitha*, Assistant Professor, Research Supervisor, PG \& Research Department of Commerce, Guru Nanak College (Autonomous), Chennai, India.

T. Punitha, Ph.D. Research Scholar, Guru Nanak College (Autonomous), Chennai, India. performed by the management. (George R Terry) in his study he says that successful and effective decision making brings success to the organization on other side ineffective decision making is the selection of two or more possible alternatives.

\section{NEED FOR STUDY}

The desire of the study is to understand the different role of performance management system in decision making process, and to examine the administrative decision making, informational decision making and developmental decision making process in software industries.

\section{OBJECTIVES OF THE STUDY}

- To study the retention strategies of software industries

- To analyze the administrative decision making process through the attributes of succession planning and reward management.

- To examine the informational decision making process through the attributes of training and development and career management.

- To study the developmental decision making process through the attributes of discipline and grievance and counseling.

\section{REVIEW OF LITERATURE}

G. Purushothamanand Krishnamurthy(2014)in their article," A study on employees performance, absenteeism, turnover and job satisfaction with special reference to hcl info systems ltd" mentioned that job satisfaction has been linked to many variables, including performance, and turnover. This study mainly engrossed on the job satisfaction level of the employees which is significant because a person's attitude and beliefs may affect his or her behavior. Attitudes make a person to work harder, or the opposite may occur, and he or she may work less. Job satisfaction also affects a person's general well being for the reason that people spend a good part of the day at work. Consequently, once a person is dissatisfied with their work, this would carry to dissatisfaction in other areas of their life. This study focuses on basis of job satisfaction of employees, the satisfaction level have variation from employee to employee. The management on the employees works for the purpose to improve the job satisfaction level 


\section{Performance Management - an Operative Instrument for Effective Decision Making}

Sunraj Panpatteand V. D Takale (2019)This study is based on the decision making process for an organizational for effectiveness. It has focused on six important steps useful for the organizational effectiveness. These are certain parameter over which we can judge decision making model.

It included the factors like risk, resource utilization, complexity impact on business real time application. This is generally coverts the several steps, identifying, analyzing and bringing solution.

\section{RESEARCH METHODOLOGY}

Sources of Data: This study based on both primary and secondary data. The primary data is collected through the questionnaires and secondary data collected from websites and journals.
Sample Size: The sample size for the study is 80 and they were collected through the way of purposive sampling technique.

Statistical Tools: The primary data are collected and analyzed with the help of statistical tools. SPSS used to analyze the collected data.

- Percentage analysis

- Descriptive Analysis

- Chi-square

VI. ANALYSIS AND INTERPRETATION

Table - 1: The Demographic Profile of The Respondents

\begin{tabular}{|c|c|c|c|c|}
\hline Socio - Factors \& Classification & Frequency & Percentage & Mean & SD \\
\hline \multicolumn{5}{|l|}{ Gender } \\
\hline Male & 52 & 65 & \multirow{3}{*}{1.35} & \multirow{3}{*}{.479} \\
\hline Female & 28 & 35 & & \\
\hline Total & 80 & 100 & & \\
\hline \multicolumn{5}{|l|}{ Age } \\
\hline $21 \mathrm{yrs}-31 \mathrm{yrs}$ & 39 & 48.8 & \multirow{5}{*}{1.837} & \multirow{5}{*}{.986} \\
\hline $31 \mathrm{yrs}-41 \mathrm{yrs}$ & 22 & 27.5 & & \\
\hline $41 \mathrm{yrs}-51 \mathrm{yrs}$ & 12 & 15 & & \\
\hline Above 51 yrs & 7 & 8.8 & & \\
\hline Total & 80 & 100 & & \\
\hline \multicolumn{5}{|l|}{ Qualification } \\
\hline Graduation & 24 & 30 & \multirow{5}{*}{2.15} & \multirow{5}{*}{1.044} \\
\hline Post-Graduation & 34 & 42.5 & & \\
\hline Diploma & 8 & 10 & & \\
\hline PG diploma & 14 & 17.5 & & \\
\hline Total & 80 & 100 & & \\
\hline \multicolumn{5}{|l|}{ Marital Status } \\
\hline Married & 45 & 56.3 & \multirow{3}{*}{1.437} & \multirow{3}{*}{.499} \\
\hline Un married & 35 & 43.8 & & \\
\hline Total & 80 & 100 & & \\
\hline \multicolumn{5}{|l|}{ Monthly Income } \\
\hline Below 25000 & 10 & 12.5 & \multirow{5}{*}{2.41} & \multirow{5}{*}{.774} \\
\hline $25000-50000$ & 31 & 38.8 & & \\
\hline $50000-75000$ & 35 & 43.8 & & \\
\hline Above 75000 & 4 & 5 & & \\
\hline Total & 80 & 100 & & \\
\hline \multicolumn{5}{|l|}{ Monthly Expenditure } \\
\hline Below 20000 & 37 & 46.3 & \multirow{5}{*}{1.687} & \multirow{5}{*}{.789} \\
\hline $20000-40000$ & 35 & 43.8 & & \\
\hline $40000-60000$ & 4 & 5 & & \\
\hline Above 60000 & 4 & 5 & & \\
\hline Total & 80 & 100 & & \\
\hline
\end{tabular}




\begin{tabular}{|c|c|c|c|c|}
\hline Years of Working in So & & & & \\
\hline Less than 1 year & 26 & 32.5 & \multirow{5}{*}{2.25} & \multirow{5}{*}{1.096} \\
\hline 1 to 5 years & 22 & 27.5 & & \\
\hline 6 to 10 years & 18 & 22.5 & & \\
\hline Above 10 years & 14 & 17.5 & & \\
\hline Total & 80 & 100 & & \\
\hline
\end{tabular}

Interpretation: From the above table it can be seen about the demographic profile of the respondents with the percentage analysis. Male is more in number having21 years to 31 years of age group followed by 31 to 41 years. Postgraduates and married are more in number. Monthly Income category Rs. 50,000 to 75,000 is the highest and expenditure falls in Below 20,000 category. Among the respondents $32.5 \%$ is the highest who have less than 1 year of experience.

\section{A. Performance management brings various aspects for the organizational success}

An industry requires more understanding of employees on the work place for the reason of managing the circumstances for the idea bringing quick fix to the problem. For determination of effective decision making practice the industry has to focus on the following methods to bring good results to the objectives.

\section{B. Administrative Decision Making}

Administrative decision making methods used to solve the problems raised in the industry. It catches some of the attributes such as succession planning and Reward management. Succession planning can be said in other word "Replacement planning". This aspect helps in identifying the talented worker in order to fulfill the future position. According to "Canadian Federation of independent business" more than one third of owners of independent business plan to exit their business with the next 5 years and within the next 10 years two third of owners plan to exit their business. This survey also found that small and medium size enterprises are prepared by the succession planning: only $10 \%$ of owner have a formal and written plan $38 \%$ of owner have unwritten plan and 52\% do not have any plan. A 2004 survey suggests that succession planning became critical issues that it is estimate by 2010 .

Table 2: The relationship between the socio economic profile and attribute of succession planning of the respondents

\begin{tabular}{|c|c|c|c|c|c|c|c|c|c|}
\hline \multirow{2}{*}{$\begin{array}{c}\text { Socio economic } \\
\text { profile }\end{array}$} & \multirow[b]{2}{*}{ Classification } & \multicolumn{4}{|c|}{ Succession planning } & \multirow[b]{2}{*}{ Total } & \multirow[b]{2}{*}{ Chi-square } & \multirow[b]{2}{*}{ Df } & \multirow{2}{*}{$\begin{array}{c}\text { Asymptotic } \\
\text { significance } \\
\text { 2(sided) }\end{array}$} \\
\hline & & $\begin{array}{c}\text { Talent } \\
\text { Retention }\end{array}$ & $\begin{array}{l}\text { Turnover } \\
\text { rate }\end{array}$ & $\begin{array}{l}\text { Supervisor } \\
\text { support }\end{array}$ & $\begin{array}{l}\text { Industry } \\
\text { growth }\end{array}$ & & & & \\
\hline \multirow{2}{*}{ Gender } & Male & 21 & 13 & 6 & 12 & 52 & \multirow{2}{*}{8.719} & \multirow{2}{*}{3} & \multirow{2}{*}{0.033} \\
\hline & Female & 7 & 10 & 9 & 2 & 28 & & & \\
\hline \multirow{4}{*}{ Age } & $21 \mathrm{yrs}-31 \mathrm{yrs}$ & 13 & 16 & 4 & 6 & 39 & \multirow{4}{*}{19.238} & \multirow{4}{*}{9} & \multirow{4}{*}{0.013} \\
\hline & $31 \mathrm{yrs}-41 \mathrm{yrs}$ & 10 & 1 & 4 & 7 & 22 & & & \\
\hline & 41yrs-51yrs & 3 & 3 & 6 & 0 & 12 & & & \\
\hline & Abv51 yrs & 2 & 3 & 1 & 1 & 7 & & & \\
\hline \multirow{4}{*}{ Qualification } & Graduation & 13 & 2 & 4 & 5 & 24 & \multirow{4}{*}{19.111} & \multirow{4}{*}{9} & \multirow{4}{*}{0.024} \\
\hline & PG & 12 & 12 & 3 & 7 & 34 & & & \\
\hline & Diploma & 1 & 3 & 4 & 0 & 8 & & & \\
\hline & PG diploma & 2 & 6 & 4 & 2 & 14 & & & \\
\hline
\end{tabular}

Ho: 'There is no significant relationship between the gender, age, qualification of the respondents and the attribute of succession planning.

Hypothesis is tested with the help of chi-square test. The calculated value of chi-square gender (8.719) age (19.238) qualification (19.111) and the $\mathrm{P}$ value are gender (0.033) age (0.013) qualification (0.024), hence the $\mathrm{P}$ value is less than the 0.05 ( $\mathrm{P}$ value $5 \%$ ).the hypothesis is rejected at $5 \%$ level of significant. Hence it is proved that the attribute of succession planning is associated with the gender, age and qualification
Reward management: It means implementation of the policies that aim to reward the employees fairly. It forms a decision in remuneration, compensation of benefits for the employees. The reward has to be honored to the highly performed employees. The management can form decision on employee's performance with the guidance of the "pay scale". Play scale helps to find out the well performed employees at the top of their pay range this helps to reward the employees. 


\section{Performance Management - an Operative Instrument for Effective Decision Making}

Table - 3: The relationship between the socio economic profile and attribute of reward management of the respondents

\begin{tabular}{|c|c|c|c|c|c|c|c|c|c|}
\hline \multirow[b]{2}{*}{$\begin{array}{l}\text { Socio economic } \\
\text { profile }\end{array}$} & \multirow[b]{2}{*}{ Classification } & \multicolumn{4}{|c|}{ Reward management } & \multirow[b]{2}{*}{ Total } & \multirow[b]{2}{*}{$\begin{array}{l}\text { Chi- } \\
\text { square }\end{array}$} & \multirow[b]{2}{*}{ Df } & \multirow{2}{*}{$\begin{array}{c}\text { Asymptoti } \\
\text { c } \\
\text { significanc } \\
\text { e } \\
\text { 2(sided) }\end{array}$} \\
\hline & & $\begin{array}{c}\text { High } \\
\text { compensatio } \\
\text { n }\end{array}$ & $\begin{array}{c}\text { Reward based } \\
\text { on } \\
\text { performance }\end{array}$ & $\begin{array}{l}\text { Recognize } \\
\text { extra work }\end{array}$ & $\begin{array}{c}\text { Work } \\
\text { independenc } \\
\mathrm{e}\end{array}$ & & & & \\
\hline \multirow[b]{2}{*}{ Gender } & Male & 23 & 7 & 14 & 8 & 52 & \multirow{2}{*}{2.493} & \multirow{2}{*}{3} & \multirow{2}{*}{0.477} \\
\hline & Female & 9 & 6 & 6 & 7 & 28 & & & \\
\hline \multirow{4}{*}{ Age } & $21 \mathrm{yrs}-31 \mathrm{yrs}$ & 19 & 10 & 8 & 4 & 41 & \multirow{4}{*}{14.491} & \multirow{4}{*}{9} & \multirow{4}{*}{0.106} \\
\hline & $31 \mathrm{yrs}-41 \mathrm{yrs}$ & 5 & 0 & 7 & 7 & 19 & & & \\
\hline & $41 \mathrm{yrs}-51 \mathrm{yrs}$ & 6 & 1 & 3 & 2 & 12 & & & \\
\hline & Abv51 yrs & 2 & 2 & 2 & 2 & 8 & & & \\
\hline \multirow{4}{*}{ Qualification } & Graduation & 13 & 5 & 5 & 1 & 24 & \multirow{4}{*}{8.344} & \multirow{4}{*}{9} & \multirow{4}{*}{0.500} \\
\hline & PG & 13 & 4 & 8 & 9 & 34 & & & \\
\hline & Diploma & 3 & 1 & 2 & 2 & 8 & & & \\
\hline & PG diploma & 3 & 3 & 5 & 3 & 14 & & & \\
\hline
\end{tabular}

Ho: 'There is no significant relationship between the gender, age, qualification of the respondents and the attribute of reward management

Hypothesis is tested with the help of chi-square test. The calculated value of chi-square gender(2.493) age(14.491) qualification(8.344) and the $\mathrm{P}$ value are gender(0.477) age(0.106) qualification $(0.500)$ hence the $P$ value is higher than the $0.05(\mathrm{P}$ value $5 \%$ ).the hypothesis is accepted at $5 \%$ level of significant. Hence it is proved that the attribute of Reward management is not associated with the gender, age, and qualification.

\section{Informational Decision Making}

Informational decision making is another mode to solve the problems. It opens up with some of the attributes such as, training and development and career management. Training, builds a critical thinking skill for the view of making effective decision. The training is based on the culture of the industry at each and every level. Successful training lead brings development and prosperity to the industry.

Table - 4: The relationship between the socio economic profile and the attribute of training and development of the respondents

\begin{tabular}{|c|c|c|c|c|c|c|c|c|c|}
\hline \multirow[b]{2}{*}{$\begin{array}{l}\text { Socio } \\
\text { economic } \\
\text { profile }\end{array}$} & \multirow[b]{2}{*}{ Classification } & \multicolumn{4}{|c|}{ Training and development } & \multirow[b]{2}{*}{ Total } & \multirow[b]{2}{*}{$\begin{array}{l}\text { Chi- } \\
\text { square }\end{array}$} & \multirow[b]{2}{*}{ Df } & \multirow[b]{2}{*}{$\begin{array}{c}\text { Asymptotic } \\
\text { significance } \\
\text { 2(sided) }\end{array}$} \\
\hline & & $\begin{array}{c}\text { Enhancing } \\
\text { Productivity \& } \\
\text { performance }\end{array}$ & $\begin{array}{l}\text { Training helps } \\
\text { to improve your } \\
\text { work }\end{array}$ & $\begin{array}{l}\text { Training is } \\
\text { well } \\
\text { Planned } \\
\text { Exercise } \\
\text { In the } \\
\text { industries }\end{array}$ & $\begin{array}{c}\text { Training helps } \\
\text { To } \\
\text { Develop } \\
\text { Industry } \\
\text { Productivity }\end{array}$ & & & & \\
\hline \multirow{2}{*}{ Gender } & Male & 17 & 22 & 2 & 11 & 52 & \multirow{2}{*}{11.038} & \multirow{2}{*}{3} & \multirow{2}{*}{0.012} \\
\hline & Female & 13 & 4 & 6 & 5 & 28 & & & \\
\hline \multirow{4}{*}{ Age } & $21 \mathrm{yrs}-31 \mathrm{yrs}$ & 15 & 17 & 3 & 6 & 41 & \multirow{4}{*}{25.134} & \multirow{4}{*}{9} & \multirow{4}{*}{0.003} \\
\hline & $31 \mathrm{yrs}-41 \mathrm{yrs}$ & 7 & 6 & 4 & 2 & 19 & & & \\
\hline & $41 \mathrm{yrs}-51 \mathrm{yrs}$ & 3 & 1 & 0 & 8 & 12 & & & \\
\hline & Abv51 yrs & 5 & 2 & 1 & 0 & 8 & & & \\
\hline \multirow{4}{*}{ Qualification } & Graduation & 12 & 4 & 2 & 6 & 24 & \multirow{4}{*}{21.451} & \multirow{4}{*}{9} & \multirow{4}{*}{0.011} \\
\hline & PG & 12 & 17 & 3 & 2 & 34 & & & \\
\hline & Diploma & 2 & 1 & 0 & 5 & 8 & & & \\
\hline & PG diploma & 4 & 4 & 3 & 3 & 14 & & & \\
\hline
\end{tabular}

Ho: 'There is no significant relationship between the gender, age, qualification of the respondents and the attribute of training and development.

Hypothesis is tested with the help of chi-square test. The calculated value of chi-square gender (11.038) age (25.134) qualification (21.451) and the $\mathrm{P}$ value are gender (0.012) age (0.003) qualification (0.011), hence the $\mathrm{P}$ value is less than the $0.05(\mathrm{P}$ value $5 \%$ ).the hypothesis is rejected at $5 \%$ level of significant. Hence it is proved that the attribute of Training and development is associated with the gender, age and qualification.

Published By:

Blue Eyes Intelligence Engineering 
Career management is the most extensive attribute for the decision making process. Employee's career is developed by the job promotions. Performance of employees decides their career and ethics are engaged with the manager and human resources in the industry. Career coaching management supports the employees for the idea of growing up their career journeyand this gives hand in employee's retention and development.

Table - 5: The relationship between socio economic profile and the attribute of career management of the respondents

\begin{tabular}{|c|c|c|c|c|c|c|c|c|c|}
\hline \multirow[b]{2}{*}{$\begin{array}{l}\text { Socio economic } \\
\text { profile }\end{array}$} & \multirow[b]{2}{*}{ Classification } & \multicolumn{4}{|c|}{ Career management } & \multirow[b]{2}{*}{ Total } & \multirow[b]{2}{*}{$\begin{array}{l}\text { Chi- } \\
\text { square }\end{array}$} & \multirow[b]{2}{*}{ Df } & \multirow[b]{2}{*}{$\begin{array}{c}\text { Asymptotic } \\
\text { significance } \\
\text { 2(sided) }\end{array}$} \\
\hline & & $\begin{array}{l}\text { Identifying } \\
\text { strength } \\
\text { skills and } \\
\text { value }\end{array}$ & $\begin{array}{l}\text { Identifying } \\
\text { experience } \\
\text { to develop } \\
\text { career }\end{array}$ & $\begin{array}{c}\text { Identifying } \\
\text { natural } \\
\text { talent }\end{array}$ & $\begin{array}{c}\text { Consider } \\
\text { qualification } \\
\text { for career } \\
\text { development }\end{array}$ & & & & \\
\hline \multirow{2}{*}{ Gender } & Male & 5 & 18 & 24 & 5 & 52 & \multirow{2}{*}{23.606} & \multirow{2}{*}{3} & \multirow{2}{*}{0.000} \\
\hline & Female & 15 & 5 & 3 & 5 & 28 & & & \\
\hline \multirow{4}{*}{ Age } & $21 \mathrm{yrs}-31 \mathrm{yrs}$ & 10 & 13 & 15 & 3 & 41 & \multirow{4}{*}{9.855} & \multirow{4}{*}{9} & \multirow{4}{*}{0.362} \\
\hline & $31 \mathrm{yrs}-41 \mathrm{yrs}$ & 5 & 4 & 6 & 4 & 19 & & & \\
\hline & $41 \mathrm{yrs}-51 \mathrm{yrs}$ & 4 & 1 & 5 & 2 & 12 & & & \\
\hline & Abv51 yrs & 1 & 5 & 1 & 1 & 8 & & & \\
\hline \multirow{4}{*}{ Qualification } & Graduation & 2 & 4 & 13 & 5 & 24 & \multirow{4}{*}{14.030} & \multirow{4}{*}{9} & \multirow{4}{*}{0.121} \\
\hline & PG & 10 & 13 & 8 & 3 & 34 & & & \\
\hline & Diploma & 3 & 1 & 3 & 1 & 8 & & & \\
\hline & PG diploma & 5 & 5 & 3 & 1 & 14 & & & \\
\hline
\end{tabular}

Ho: 'There is no significant relationship between the gender, age, qualification of the respondents and the attribute of career management',

Hypothesis is tested with the help of chi-square test. The calculated value of chi-square gender(23.606) age(9.855) qualification(14.030) and the $\mathrm{P}$ value of gender(0.000) hence the $\mathrm{P}$ value of gender is less the 0.05 hence it is proved that the attribute of career management is associated with gender. Age (0.362) qualification $(0.121)$ hence it is proved that the $P$ value is higher than the 0.05 (P value 5\%). The hypotheses are accepted at $5 \%$ level of significant. Hence it is proved that the attribute of career management is not associated with the age, and qualification.

\section{Developmental Decision Making}

Departmental decision making shows a great deal with some of the attributes such as discipline and grievance and counseling. Discipline and grievance can be said in simply that it deals with employee's problem and complaints. The employee's performance is not satisfied with the management. The complaints field and gets into the hands of manager works is to analyze and brings solution to the problem.

Table - 6: The relationship between socio economic profile and the attribute of discipline and grievance of the respondents

\begin{tabular}{|c|c|c|c|c|c|c|c|c|c|}
\hline \multirow[b]{2}{*}{$\begin{array}{l}\text { Socio economic } \\
\text { profile }\end{array}$} & \multirow[b]{2}{*}{ Classification } & \multicolumn{4}{|c|}{ Discipline and Grievance } & \multirow[b]{2}{*}{ Total } & \multirow[b]{2}{*}{$\begin{array}{l}\text { Chi- } \\
\text { square }\end{array}$} & \multirow[b]{2}{*}{ Df } & \multirow[b]{2}{*}{$\begin{array}{c}\text { Asymptotic } \\
\text { significance } \\
\text { 2(sided) }\end{array}$} \\
\hline & & $\begin{array}{l}\text { Aware of } \\
\text { the problem }\end{array}$ & $\begin{array}{l}\text { Problem } \\
\text { discussed } \\
\text { with the } \\
\text { union } \\
\text { members }\end{array}$ & $\begin{array}{l}\text { Reported } \\
\text { immediately }\end{array}$ & $\begin{array}{l}\text { Management } \\
\text { has taken steps } \\
\text { to solve the } \\
\text { problem }\end{array}$ & & & & \\
\hline \multirow[b]{2}{*}{ Gender } & Male & 8 & 13 & 15 & 16 & 52 & \multirow{2}{*}{9.793} & \multirow{2}{*}{3} & \multirow{2}{*}{0.020} \\
\hline & Female & 13 & 3 & 7 & 5 & 28 & & & \\
\hline \multirow{4}{*}{ Age } & $21 \mathrm{yrs}-31 \mathrm{yrs}$ & 12 & 5 & 16 & 8 & 41 & \multirow{4}{*}{18.126} & \multirow{4}{*}{9} & \multirow{4}{*}{0.034} \\
\hline & $31 \mathrm{yrs}-41 \mathrm{yrs}$ & 5 & 8 & 0 & 6 & 19 & & & \\
\hline & $41 \mathrm{yrs}-51 \mathrm{yrs}$ & 2 & 2 & 5 & 3 & 12 & & & \\
\hline & Abv51 yrs & 2 & 1 & 1 & 4 & 8 & & & \\
\hline \multirow{4}{*}{ Qualification } & Graduation & 12 & 6 & 1 & 5 & 24 & \multirow{4}{*}{19.127} & \multirow{4}{*}{9} & \multirow{4}{*}{0.024} \\
\hline & PG & 3 & 8 & 14 & 9 & 34 & & & \\
\hline & Diploma & 2 & 1 & 2 & 3 & 8 & & & \\
\hline & PG diploma & 4 & 1 & 5 & 4 & 14 & & & \\
\hline
\end{tabular}




\section{Performance Management - an Operative Instrument for Effective Decision Making}

gender, age, qualification of the respondents and the attribute of discipline and grievance.

Hypothesis is tested with the help of chi-square test. The calculated value of chi-square gender (9.793) age (18.126) qualification (19.127) and the $\mathrm{P}$ value of gender (0.020) age (0.034) qualification (0.024), hence the $P$ value is less than the $0.05(\mathrm{P}$ value $5 \%$ ).the hypothesis is rejected at $5 \%$ level of significant. Hence it is proved that the attribute of discipline and grievance is associated with the gender, age and qualification.

\section{Counseling}

Table 7: The relationship between socio economic profile and the attribute of counseling of the respondents

\begin{tabular}{|c|c|c|c|c|c|c|c|c|c|}
\hline \multirow[b]{2}{*}{$\begin{array}{l}\text { Socio economic } \\
\text { profile }\end{array}$} & \multirow[b]{2}{*}{ Classification } & \multicolumn{4}{|c|}{ Counseling } & \multirow{2}{*}{ Total } & \multirow[b]{2}{*}{ Chi-square } & \multirow[b]{2}{*}{ Df } & \multirow{2}{*}{$\begin{array}{c}\text { Asymptotic } \\
\text { significance } \\
\text { 2(sided) }\end{array}$} \\
\hline & & $\begin{array}{l}\text { Helps to } \\
\text { think better }\end{array}$ & $\begin{array}{l}\text { Helps to } \\
\text { behave } \\
\text { better }\end{array}$ & $\begin{array}{l}\text { Helps to } \\
\text { understand } \\
\text { the situation }\end{array}$ & $\begin{array}{l}\text { Helps to } \\
\text { make } \\
\text { decision }\end{array}$ & & & & \\
\hline \multirow[b]{2}{*}{ Gender } & Male & 19 & 16 & 13 & 4 & 52 & \multirow{2}{*}{1.191} & \multirow{2}{*}{3} & \multirow{2}{*}{0.755} \\
\hline & female & 9 & 7 & 8 & 4 & 28 & & & \\
\hline \multirow{4}{*}{ Age } & $21 \mathrm{yrs}-31 \mathrm{yrs}$ & 18 & 16 & 3 & 4 & 41 & \multirow{4}{*}{30.624} & \multirow{4}{*}{9} & \multirow{4}{*}{0.000} \\
\hline & $31 \mathrm{yrs}-41 \mathrm{yrs}$ & 3 & 2 & 13 & 1 & 19 & & & \\
\hline & $41 \mathrm{yrs}-51 \mathrm{yrs}$ & 2 & 4 & 4 & 2 & 12 & & & \\
\hline & Abv51 yrs & 5 & 1 & 1 & 1 & 8 & & & \\
\hline \multirow{4}{*}{ Qualification } & Graduation & 11 & 6 & 6 & 1 & 24 & \multirow{4}{*}{5.651} & \multirow{4}{*}{9} & \multirow{4}{*}{0.774} \\
\hline & PG & 11 & 11 & 7 & 5 & 34 & & & \\
\hline & Diploma & 2 & 3 & 2 & 1 & 8 & & & \\
\hline & PG diploma & 4 & 3 & 6 & 1 & 14 & & & \\
\hline
\end{tabular}

Ho: 'There is no significant relationship between the gender, age, qualification of the respondents and the attribute of counseling',

Hypothesis is tested with the help of chi-square test. The calculated value of chi-square gender(1.191) age(30.624) qualification(5.651) and the $\mathrm{P}$ value of age (0.000) hence the $\mathrm{P}$ value of age is less the 0.05 hence it is proved that the attribute of counseling is associated with age .Gender(0.755) qualification (0.774) hence it is proved that the $\mathrm{P}$ value is higher than the 0.05 ( $\mathrm{P}$ value 5\%). The hypotheses are accepted at $5 \%$ level of significant. Hence it is proved that the attribute of counseling is not associated with the gender and qualification.

\section{FINDINGS}

- It is clear that the demographic profile of the respondents with the analysis of mean value and standard deviation. The high weighted mean value is 2.41 of monthly income; second highest mean value is 2.25 of years of working in software industries and the next highest 2.15 mean value of qualification.

- The attribute of succession planning is associated with the gender, age and qualification

- The attribute of Reward management is not associated with the gender, age, and qualification.

- Training and development is associated with the gender, age and qualification.

- The attribute of career management is not associated with the age, and qualification.
The next attribute is counseling it has a great deal in releasing complication of work and stress. The counseling is given by the highly trained professional counselors. By reducing the employee's complication over the work support the industry to carry their day today work with full relaxed mind of employees. This makes them to focus on their job retention and promotion.
- it is proved that the attribute of discipline and grievance is associated with the gender, age and qualification.

- The attribute of counseling is not associated with the gender and qualification.

\section{SUGGESTIONS}

This study targeted on effective decision making process in software industries. The suggestion for this study is mainly based on the administrative decision making (succession planning, Reward management) informational decision making (Training and development, career management) Developmental decision making (Discipline and grievance, counseling).

- Well planned and designed succession planning is critical to industrial success. Thus the industries should place a good succession strategy; this would give hand to the manager and HR.

- There are many different ways to motivate employees but by motivating one employee the other employee may not be necessarily motivated so the manager should take care of all employees' interest and willingness in work place

- All manager and HR are should be well trained in the goal of employees comfort in work place.

- Training system should be developed according to the changes of technology.

- The management should concentrate on employee's satisfaction with the training practices. 
- Promotion should be clearly encouraged by the management for the motive of employee's career development.

- Career counseling should be given to the employees in developing their career.

- The industry should provide suggestion box for the purpose of getting employees suggestion in problematic situation.

- Interaction with employees is must followed by the management.

- The industries need a separate counseling cell and it should have well trained and qualified counselors for conducting counseling.

\section{CONCLUSION}

This study determine that performance management systems gives hand in making an effective decision making process in industries. The attributes are more helpful to the managers and HR in finding out the problem for the intent of making decision and bringing solution as faster as the other procedure and stages. Since with the help of administrative decision making, informational decision making and developmental decision making the workers feel very comfortable in bringing the problems to the management and they are more satisfied with the decision taken to solve the problem by the management. So this process helps the management to carry their goals towards their success.

\section{REFERENCES}

1. Alexander David Norman (2015) "An Investigation into the perceptions of employee performance management in the UK retail industry" pp210-235

2. Dr. Charles Kombo Okioga ( 2013) "The contribution of Human Resource strategies to the Organizational Success"European Journal of Business and Management Vol.5, No.6, 2013

3. Dr. S. Gomathi "A study on grievance management improving employees performance" journal of social science Vol 5 NO: 20 sep 2014

4. Sunraj Panpatte, V.D Takale "To study the decisionmaking process in an organization" journal of business management and technology Vol 3 issue 1 jan -feb 2019

\section{AUTHORS PROFILE}

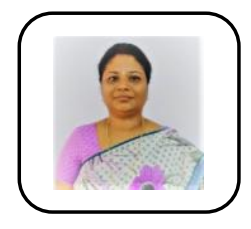

Dr. M. Kavitha, M.Com. MBA, M.Phil, Ph.D. is serving as an Assistant Professor in Guru Nanak College (Autonomous), Chennai and qualified SET in Commerce and SET in Management with 15 years of UG , 11 years of PG Teaching and research experience (Masters and Doctorate Level). Recognized Research Supervisor of University of Madras. Currently 7 candidates are pursuing their $\mathrm{Ph} . \mathrm{D}$. under her guidance. Evaluator of academic projects and trainer for FDP. She has experience in providing coaching for Soft skills and Personality development programmes for UG and PG students. She is an Academic counsellor, Project Guide and Evaluator of IGNOU, Board of examiners of University of Madras and other universities and autonomous colleges. Executive Editor of Guru Nanak Journal of Multi-Disciplinary Research- special issues. To her credit she published more than 50 articles in reputed journals and conference volume proceedings, participated and presented several papers in many national and international conferences. She has successfully completed the ARPIT course of MHRD. She is a Women-in-charge of commerce department and Department Co- ordinator of IQAC . Organizing committee member of national and international conferences and serving as member in several committees and event organizer of various academic programme.

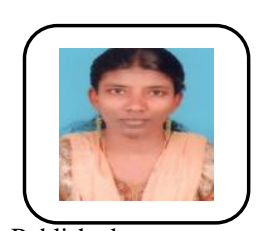

Ms. T. Punitha, is currently doing her Ph.D. research under the guidance of Dr. M. Kavitha, Assistant Professor of Commerce, Guru Nanak College. She completed M.Com with distinction in The Quaide Milleth College For Men, and passed her M.Phil with distinction in Dhanraj Baid Jain College, Her specialization is Human Resource Management. She Published two research articles in leading journals. She presents papers regularly in various conferences. She participated workshops and seminars. She gained Proficiency Prizes during her B.Com. and M.Com., courses for securing highest marks in her subjects. 